\title{
An Analytical Overview of Book Publishing and Copyright Issues in Pakistan
}

\author{
Muhammad Asif ${ }^{1}$, Liu Yang ${ }^{2}$, Majid Ali $^{3}$, Muhammad Hashim ${ }^{4}$ \\ ${ }^{1}$ Postdoctoral Researcher School of Journalism and Communication, Hunan Normal University, Changsha, China \\ asifanu@hotmail.com \\ 2 School of Journalism and Communication, Hunan Normal University, Changsha, China \\ 261630079@qq.com \\ ${ }^{3}$ Lecturer in Law College Faisalabad, Pakistan \\ majidpak22@gmail.com \\ ${ }^{4}$ Assistant Professor School Management Sciences, National Textile University, Faisalabad, Pakistan \\ mhashim@ntu.edu.pk
}

\begin{abstract}
The research investigates the issues confronting the Pakistani book publishing sector since books are an efficient means of communication for rhetoric. A theoretical research approach was chosen, and secondary information was acquired by examining numerous relevant and genuine sources. The study has used functionalism and value change theory; it indicates that an individual should know the subject accurately before modifying their values. Each subsystem is expected to contribute significantly to the society's continuity and orderly functioning. The book is necessary for the continued survival, progress, and advancement of civilization. Without any of the publishing sector, there would be no books. Book publication plays a vital role in every civilization since it allows for the spread and diffusion of information. It is a component of a knowledge distribution system. There have been issues confronting the Pakistani book publishing sector, such as poor reading culture, government regulation, piracy, Improper finance, and a lack of knowledge. The study sugges ts that stakeholders develop creative solutions that can meet the industry's people and material requirements. According to the investigation, stakeholders in the publishing sector should develop a healthy publishing industry. Private investors, such as financial institutions and influential people, should contribute significantly to the massive capital inflow. The government should begin developing strategies to reduce the issue of piracy and charge lower import tariffs on publishing appliances. The problem of book piracy is rooted in social, economic, scholarly, and legal factors. Finally, publishing companies should make it a point to provide their technical employees with appropriate technicaleducation.
\end{abstract}

Keywords: Functionalism and Value Change Theory, Books, Issues ofBook Publishing, Copyright.

\section{Introduction}

The standard of its literature can only measure the level of a nation's civilization, culture, and growth. As Khalid (1994) points out, "books are the most vital and most successful way of learning and training the next generation." They contribute to a better understanding of current cultural upheavals and provide new parts of the population the chance to become active participants in the development process. Textbooks are essential tools in the process of transformation and growth. Besides being a powerful educational and communication tool, it also serves as a source of enjoyment and mental relaxation for its users. Books are the most efficient and cost-effective means of accomplishing educational advancement, conveying knowledge, as well as recording, protecting, and spreading the Nation's cultural legacy (Altbach \& Rathgeber, 1980, p.34). Books remain the most effective 
communication vehicle in this era of information and communication explosion and technological innovation.

The book is considered a stimulant for mental development and social integration. The book seems to be a mass communication medium that promotes the successful use of other media. It is also a source of national unity and development and a grand index of technology, governance, politics, religion, economics, sociology, medicine, and engineering, to name a few (Awoniyi, 1979). According to Kalejaye and Akangbe (2007), the book is a multifaceted, dynamic product with a colossalcontribution to any civilization. They believe;

Teachers and students, researchers and experts, and casual readers alike find the book as a treasure trove of information and entertainment. A book is a measurement of success, a sign of stability, and a source of inspiration and motivation. It is also a springboard for progression and a catalyst for the breakthrough.

When it comes to literacy growth, books have an indefinable influence, and as such, it is possible to link a nation's development to its literacy levels. A more developed civilization is a book-obsessed culture, whereas an underdeveloped society is less book-oriented. A nation's progress may be traced back to its ability to produce books. Without the invention of book printing, the records and the academic knowledge and ideas of education legends such as Aristotle, Socrates, and Descartes, would not have been preserved for posterity but would have been lost to humanity. Furthermore, publishing is an intellectual and social obligation for preserving the record of human activity for future generations. According to Nyeko (1991), literacy creates materials for diffusion such as books, films, computer programs, recordings, newspapers, journals, C.D.s, bulletins, and magazines. Thus, the word "publication" refers to the act of creating literacy and information products for public use (Carter \& Pattis, 2001). At the time of the partition in 1947, the majority of non-Muslimowned publishing businesses relocated to India. The number of Muslim-owned textbooks and religious book publishing companies was insufficient to fill the void; as a result, several other publishers and booksellers joined the industry to meet the rising demands of the new country (Shah, 1963: p.21). Lahore and Karachi became major publishing centers. In the 1950s, surplus dictionaries of indigenous languages and school textbooks were developed as "self-determination" (PBWG, 1972). Unfortunately, despite its increased size and structure, the industry has been plagued by several obstacles. Today, now than at any other point in history, as kalejaye and akangbe (2007) concur, it faces more severe limits. On this assumption, this paper investigates and discusses the avalanche of difficulties that endanger and hobble the industry's possibilities and the need to confront those limits head-on and find long-term solutions, as the author intends to achieve in the study's suggestions.

\section{Methodology}

To make their arguments, the researchers use a descriptive technique and rely...on...secondary...s.ources...s.uch. as newspapers, magazines, libraries, archives, and other desk studies to support their arguments. It explored the issues that the Pakistani book publishing industry faces from the viewpoints of those involved in the sector. The findings were presented in a study.

\section{Theoretical Framework}

\section{Value Change and Functionalism Theory}

The study makes use of the value change theory. Value change theory is a variation of the psychodynamic model that is based on social-scientific perspectives on persuasion. According to Bradley \& Lang (2000), persuasion is the process whereby an effort is made to modify an individual's or group's attitude and behavior via engaging a person's or group's cognitive and emotional processes. The Value Change hypothesis use "Comparative Feedback" to influence society's attitudes and behaviors. It is committed to alerting the public about an entity's deleterious and helpful effects, such as the Pakistani book publishing sector. Its elf by contact with those in positions of power who are assumed to be socially accountable for the operation of such corporate life. The idea supports a person or community modify ing their values to remove "self-dissatisfaction and will," since values underpin attitudes that activate positive responses or conduct in response to a hot challenge. According to the idea, conscious purpose message transmission and behavioral impact open new avenues for value change, which results in commensurate changes in attitudes and behavior toward the challenge. It indicates that an individual(s) should get accurate knowledge about the subject before modify ing their values. It is the specific state of purchasing power of individuals that causes them to modify their purchase behavior. Because of the low income of the people in a society, they are compelled to purchase ine xpensive books, and as a result, individuals in developing nations such as Pakistan have begun to purchase pirated books, which is a violation of the country's copyright laws.

According to Merton (1957, as stated in McQuail, 2000:78), functionalist (functionalis m) philosophy seeks to explain social behaviors and institutions in societal and individual needs. The demands of the society include education, continuity, order, integration, motivation, direction, socialization, and adaptability, among others. McQuail (2000: 81) as serts that functionalist theory views mass media as critical to society's integration and cooperation, discipline, control, and stability, as well as the continuation of culture and values. The significance of books in the socio-economic, political, and technical evolution of civilization has been covered in this study. According to functionalist theory, society is a continuous system of interconnected subsystems: mass media, including books. Each subsystem is expected to contribute significantly to the society's continuity and orderly functioning. The book is necessary for the continued survival, progress, and advancement of civilization. 
Without any of the publishing sector, there would be no books.

\section{Literature Review \\ Meaning of Book}

The United Nations Educational, Scientific, and Cultural Organization conducted a study on the availability of books worldwide and defined a book as a non-periodic printed product with a minimum of 49 pages, o mitting the cover page. They separated this concept into five critical components that differentiate a book from other forms of media. These components are as follows:-

- A book is printed: Rather than being written or drawn by hand, it is manufactured using more machines.

- A book is published in that it is printed in many copies for distribution to its writers.

- A book must have at least 49 pages: Explicitly, the UNESCO definers intended to prohibit small works referred to as pamphlets, not books.

- A book is enclosed on a cover.

- A book is not a periodical: unlike periodicals and newspapers, it is not updated regularly under the same title.

\section{History of Book}

While the book's history dates back to roughly 600 years, the book's concept is considerably older. The papyrus roll, which originated in Egypt approximately 3000 B.C., is an early predecessor of the contemporary book. Papyrus was a reed-like plant that grew in the Nile Valley and looked like paper. Scribes spread papyrus sheets, wrote on them, copied a text on one side, and folded the completed manuscripts. The Egyptians also gave the Greeks the papyrus roll. They kept their rolls in massive libraries. The Greeks regarded the book as so significant that they started to rely on it rather than the memory of speeches (oral tradition) as the primary means of disseminating ideas to a broad audience. Many enormous volumes are copied by hand at scriptoria, which are maintained by library collections. Sadly, only a tiny portion of these documents has survived (Grannis, 1967).

Apart from libraries, the Romans adopted the Greek concept of papyrus rolls, and a vast number of Romans, particularly those of the higher class, acquired writings. The popularity of their works sparked a small-scale Roman papyrus roll business. Publishing firms employed slave labor to produce a large nu mber of copies at a cheap cost. Surprisingly, these businesses served as prototypes for contemporary publishing in many respects. The texts to be published or created were chosen by Roman publishing. From slave-driven papyrus roll enterprises to a random cottage, it had been a long journey. Part of the difference is due to the book's appearance (format) and the technology used to create it; around AD 100, Christians produced the Codex, a document in which papyrus sheets were tied together rather than rolled up, giving the manuscript the appearance of a book. This format lets readers rapidly locate a specific paragraph without unraveling a vast role and allows writers to write on both sides of pages. Advancements followed the Codex in manuscript materials, such as animal skins (vellum and patchment) and paper by the 15th century (Olaniawo, 1996).

Around 1300BC, the Chinese began making books out of wood and bamboo. Emperor Shih Hung Ti burned many books in $213 \mathrm{BC}$, but some of them persisted; in roughly 190BC, a library collecting dispute between Ptolemy V of Egypt and Eumenes of Pergamum resulted in the development of the skinned animal. It was created when Ptolemy imposed a papyrus embargo in order to prevent Eumenes from expanding his library. Interestingly, Johannes Guttenberg's creation of the portable printing machine sparked the emergence of contemporary book production. Since then, the printing Guru has been credited for increasing the mass manufacturing of printed material. Gutenberg's most famous inventions, his forty-two-line bibles, are remarkably stunning even by today's printing standards. Moving type printing was instantly recognized as a genuinely extraordinary technical leap over woodblock printing. His ideas promptly took on, and by 1500 , printing presses had been installed in 242 cities across many nations (Lai, 2000).

\section{Evolution of Book Publishing in Pakistan}

The printing press arrived in the Mughal capital as South Asia entered the modern period, and newspapers and printed books emerged. They were instrumental in promoting the rise of social movements via their publishing. Sir Saiy id Amad Khan, the originator of Islamic modernis $\mathrm{m}$, was these groups' most prominent 19th-century pioneer. Muslims in South Asia were tremendously benefited by his efforts to provide modern education. Maulana Saiyid Abu Al-A la Maududi (19031977) created the Islamic Party in South Asia in the 20th century and significantly affected the party's progress as Robinson argues that during the 19th and 20th centuries, the popularization of formal religious knowledge via South Asian print media was strongly linked to the Muslim religious resurgence. The mass reading of works to writers by copyists, often in a mosque, facilitated their diffusion (Robinson, 1993).

The importance of the East India Company during the early stages of printing cannot be overstated. Formed in 1600, this massive trading organization in London produced various paper documentation for its administration (Pickett, 2011). Under the supervision of Charles Wilkins (1749-1836), the company's press in Calcutta published both British government legislation and commercial publications. In 1818, the Bible Society in London printed Henry Martyn (1781-1812)'s Hindustani/Urdu prayer book using Persian typefaces. By 1825, printers in the British capital had published over 20,000 Persian, Arabic, and Urdu religious volumes (Green, 2009). In the Indian Subcontinent, the first Litho press in Urdu was built in Kanpur in 1830, followed by several more in Delhi and Lucknow. In 1848, a total of 
11,458 copies of 42 works, the majority of which were poetry and literature, were published (Ali, 1967). Private Publishing House in Lucknow in 1858 prompted Nawal Kishore to establish his press, the Nawal Kishore Press, which produced Urdu, Hindi, and Sanskrit, Arabic, and Persian works as promoting the advancement of literature (Suzuki \& Tanaka, 1974). One of the two printing presses in the city had been operational by 1859. Koh-i Nur and Darya-i Nur each produced a newspaper and eighteen books in 1850. (Ali, 1967). Hand-powered presses in Lahore produced reprints of religious and medical texts from the Islamic and Hindu religions, primary school textbooks, folk stories, and popular songs.

There was little or no interest in history, science, and travel (Punjab Government, 1989). Pakistan's Development of a Publishing System Most Non-Muslim publishing firms relocated to India during the 1947 split. Numerous new publishers and booksellers joined the industry to satisfy the expanding demands of the new country since there were not enough Muslim-owned publishing firms of textbooks and religious materials to fill the void (Shah, 1963). The publishing sector thrived in Lahore and Karachi. Self-reliance was celebrated in the 1950s by mass-producing dictionaries of local languages and school textbooks (PBWG 1972). It was not uncommon for bookstalls to pop up in West Pakistan to cater to travelers and tourists, newsagents and hawkers, rental libraries, pavement retailers, cooperative bookshops, second-hand bookshops, and foreign publishers. They were joined by educational institutions, government agencies, and general publishers in producing reading materials for the general public (Shah, 1963). In 1970, there were 111 public libraries in East Pakistan and 123 in West Pakistan. Following Lahore, Karachi had the most publishers and booksellers of any city, with 181 in total; this was followed by Dacca (122), Rawalpindi (15), Hyderabad (14), and Peshawar (9). UNESCO's 1980 study said that there were 3,000 bookstores in total, including seasonal ones, ten years later (UNESCO, 1980). Public libraries are located in over 60 cities around the country (Shamsuddoulah, 1970). There are over eight million books in Pakistan's libraries, with around 75\% concentrated in Karachi, Lahore, and Rawalpindi. Finally, the nation has over 2,000 printing presses, but most of them are manually handled, as they were during British rule. Most publishers produce little more than ten titles every year.

Additionally, writers publish a substantial quantity of books. Each year, around 3,000 volumes, excluding textbooks and children's literature, were released. The printed editions are limited to between 1,000 and 2,000 copies (UNESCO, 1980). However, Lahore was formerly a thriving center of the Indo-Pakistani book industry (Shah, 1963). Male newspaper readers outnumber female magazine and journal readers in East Pakistan. Novels and short-story-dramas accounted for over half of all books read, or $46 \%$, followed by religious, criminal, and adventure literature. Pakistan published $40 \%$ of all books;
India published $52 \%$, while other countries published $8 \%$ (Bengali Academy, 1964).

Pakistan has a great legacy of knowledge and study, but books are no longer a high priority in our everyday lives owing to rapidly changing attitudes and the availability of simple, quick, and entertaining means of communication. We have lost touch with our predecessors' unparalleled passion for information and reading. In Pakistan, publishing is not acknowledged as a distinct business and is typically associated with printing; sufficient attention has never been devoted to this subject. Since independence, the publishing sector has been less active and not regulated by any specific legislation; nonetheless, laws are being placed on the publishing industry. Publishing technology and the publishing environment are the two most important variables influencing book output in any nation, and both are lacking in Pakistan. The trade suffers from a severe lack of technology. There is no structure to train and prepare professional workers for book production, such as designers, illustrators, translators, types etters, printers, and binders.

On the one hand, there are no monetary or academic incentives for authors and editors, yet on the other hand, low literacy rates, bad reading habits, and terrible economic circumstances are critical impediments in the sphere of book creation. Non-Muslims like Athar Chand Kapur, MunshiGulab Singh, SardarSant Singh, Thakur DevAnand, Atma Ram \& Sons, Rama Kirshna and Sons, and others controlled a substantial portion of the book business before independence (NDFC, 1987). In the middle of the 16th century, printing arrived in India as a result of religion. The first printing press emerged in India in 1556 as a gift from the Portuguese government to Emperor Akbar, and the Portuguese Catechism Doctrina Christa was published in India (Goa) in 1557. Printing extended progressively from its origins in Goa and religion to other cities and encompassed secular issues. In the 18th century, literary and cultural works began to develop in Indo-Pak (Abul Hassan, 1994).

As during decline of the Mughal Empire, patronage of book production was gradually transferred from kings and nobles to the much-growing range of the elite, until the introduction of the printing press in northern IndoPakistan in the last quarter of the 18th century, which brought books within reach of the ordinary person for the first time in the Subcontinent. Charles Wilkins created the first typeface and produced the first Persian and Urdu books in India and Pakistan (Ali, 1967). The 19th century was a time of dramatic shifts in the world's political, cultural, and historical landscapes. Social norms and standards were fundamentally restructured due to fast advances in science, technology, commerce, business, and agriculture during that time. A new orientation and dimension emerged in the study and writing in this century as a result. Fort William College was built in Calcutta, India, in 1800 to educate and train incoming British employees how to engage and understand the Culture of the indigenous peoples; this was done to enable the East India Company to maintain a strong connection 
with the indigenous peoples. When Dr. William Gilch rist established this institution in honor of the Urdu language, he respected it. In addition to teaching Indian languages, Fort William College also had to print and compile or translate publications on a big scale in the Indo-Pak region. All Indian languages were used for book authoring, publication, and compilation, but Urdu was the primary emphasis of the institution. Urdu prose was revived at the college, which was seen as a place of renewal. Urdu literature and language became more widely known thanks mainly to universities and other post-secondary educational institutions. Founded in 1825, Delhi College was established by the British government in order to educate Indian youth in Eastern and Western knowledge, English language, and literature. The second phase of collection and publication of Urdu Prose was begun at Delhi College, and it was India's second-largest educational publishing and literature-producing institution, promoting the use of all Indian languages, mainly Urdu (Sami, 1988: Minault, 1999).

Nawal Kishore played a pivotal contribution in the history of Urdu printing. Kishore arranged for the translation into Urdu of various Arabic, Persian, and Sanskrit texts. He also wrote several Urdu novels in his style, focusing on the literary work of traditional poets. Additionally, he authored renowned dictionaries (Aqeel, 2014). Aligarh Scientific Society- The scientific organization was founded in Gazipur in 1864 and afterward relocated to Aligarh upon Sir Syed's relocation. This society's primary objective was to translate essential scientific and technical literature from the English and European languages into Indian and Urdu. Darul Musannifin, Azamgarh-DarulMusannefin (Shibli Academy) was founded in 1914 by MaulanaShibliNaumani's followers under the leadership of Moulana Hamid Uddin Farati. The Academy was founded to form and nurture a community of academic authors, offer a conducive atmosphere for scholars to write, collate, and translate literary works of high scholastic and historical significance, and print and disseminate the Academy's literary work. The Academy has produced about 250 (two hundred fifty) publications, including seminal works on Sirat-un-Nabi and Al Farooq. It has edited and assembled 100 volumes of work by its peers. Apart from these organizations, numerous other publishing educational institutions made significant contributions to Urdu language publishing, and some deserve particular attention here: Delhi Society 1865, Delhi College 1829, University Oriental College, Lahore 1870, and DarulTarjuma. JamiaUs mania 1917, JamiaMilliaIslamia 1920, Indian Academy Illahabad 1927, Jama-Urdu, Aligarh, Nidwat-ul-Musannafin, Sindh Madars-tul-Islam Karachi, Muhammadan Educational Conference (Aligarh), Anju manHimayat-e-Islam Karachi, Muhammadan Literary Society, Culcutta, Muhammadan Educational Conference (Aligarh), Muhammadan, all of these literary groups contribute to the enrichment of the Urdu language.
They first produced works on language, grammar, lexicon, epics, and tales, but by the mid-seventh century, they expanded to include science, biographies, Urdu essay, critical writing, novels, satire, etc., comedy. A mong non-Muslim publishers and printers, several prominent Muslim publishers founded well-known publishing firms, including Dar ul-Ishaat, Feroz Sons, Shaikh Ghulam Ali \& Sons, Malik Fazal Din, Haji Chiragh Din Siraj Din, Malik Din Muhammad, and Sheikh Mubarak Ali. Shaikh Muhammad Ashraf, M. Sanaullah Khan. Taj Hotels, Sheikh Barkat Ali, and others. After Independence; When Pakistan gained independence on 14 August 1947, it had a relatively underdeveloped industrial base and less than $17 \%$ literacy rate. Lahore was the most prominent hub of book publishing activity on the Subcontinent before independence, and at the time of independence, Lahore acquired a well-developed infrastructure of publishing enterprises. Dar ul Isha'at Punjab, Feroz Sons, Punjab Book Depot, Qumi Kutub Khana, Urdu Markaz, and Chaudhry Barkat Ali were leaders. Karachi came in second place in Lahore in terms of publishing activity. After being named the country's capital, the city flourished enormously and became the focus of all commercial operations, including printing. Today, Karachi is the country's leading English-language publisher. Following the capital's relocation from Karachi to Islamabad, the twin cities of Islamabad and Rawalpindi developed into a new publishing hub. Apart from these three cities, the Nation lacks a significant Urdu and English language publishing industry. Regional language boards and academies dominate regional language publishing, which provincial or federal governments primarily fund. While some publishers have a strong position in their respective disciplines and are attempting to retain their reputation and standards by publishing high-quality books by academics and professional authors, a small number of them restrict their work only for commercial reasons.

Textbook publishing has a distinct season, and these seasonal booksellers or publishers engage in other trades and capitalize on possibilities to produce or sell books during the textbook season. Additionally, these merchants benefit from our old and deficient educational system by producing guidebooks, keys, guess papers and solved papers during exams. The translation is another method of publication. When there is a severe shortage of quality authors, publishers attempt to publish successful foreigntitled novels in their tongue to increase the number of translated books accessible in the local market. Significant Book Publishing Organization, the government has created several organizations to develop policies and strategies to promote and support publishing.

Additionally, the government has established taskoriented organizations to publish on a wide-scale specialized character work that is unattractive to private publishers. Universities, academic institutions, and research organizations are all significant segments of the publishing industry. Apart from commercial publishing, several scholarly organizations and supported institutions have been created in Pakistan due to a strong desire to 
conserve and promote the country's cultural and intellectual history via books. They have publishing programs, although their operations in Pakistan are statistically among the smallest in the world. The Text Book Boards publish textbooks; they are Pakistan's largest book publisher, and in 1960, provincial textbook boards were established. By 1962, the publication of textbooks was centralized under governmental oversight; before, private publishers produced textbooks that the appropriate education department agencies officially authorized. In 1962, East Pakistan Text Book Board and West Pakistan Text Book Board were founded. Pakistan's four provinces currently have provincially run textbook boards that create books for grades 1 to 12 (Barnett, 1994, p.40). In 1960, the National Book Council of Pakistan was created as the National Book Center of Pakistan. It was renamed the National Book Council of Pakistan in 1975 (Sheikh, 1989, P.1). By 1962, the publication of textbooks was totally centralized under governmental oversight; before, private publishers produced textbooks that the appropriate education department agencies officially authorized. In 1962, East Pakistan Text Book Board and West Pakistan Text Book Board were founded. Pakistan's four provinces currently have provincially run textbook boards that create books for grades 1 to 12 (Barnett, 1994, p.40). In 1960, the National Book Council of Pakistan was created as the National Book Center of Pakistan. It was renamed the National Book Council of Pakistan in 1975. (Sheikh, 1989, P.1). It is responsible for the marketing of books across the Nation. The government established the National Book Foundation of Pakistan in 1972 by a National Assembly Act. The foundation's mission is to encourage authors and book merchants to create books and make them affordable to students and the general public. The foundation has been an ardent and vocal supporter of book marketing. N.B.F. has released 226(two hundred twenty-six) books since its beginning. Both of the organizations, as mentioned earlier, N.B.C. and N.B.F., have been amalgamated. The UNESCO Regional Office for Culture and Book Development in Asia was established in 1958 in Karachi as a consequence of the organization's 1955 reading materials initiative for South Asia (Sheikh, 1989, p.2)

The Center has developed several resources for Asian countries and gives vital information on book production and marketing in Pakistan. Despite an adverse and undersupported climate, certain publishers are contributing to the publishing industry's growth. The West Pakistan Urdu Academy in Lahore was founded in 1955 to enrich the Urdu language via book publication. There are around 188(one hundred eighty-eight) publications by the Academy on various disciplines, including physics, psychology, philosophy, sociology, finance, Iqabliyat, and literature. Majlis Tarraqi-e-Adab Lahore credited 278 books and reproductions of classics in their 2014 inventory of releases. Central Urdu Board, renamed Urdu Science Board, is a well-known name in Urdu science and history publication. Since its inception, the Board has published around 800 (eight hundred) volumes. Anjuman
Tarraqi-e-Urdu is one of the oldest learned organizations in Indo-Pakistan, and it made significant contributions to Urdu publication after independence; this Anjuman Tarraqi-e-Urdu has published around 650(six hundredfifty) books. MuqtadirahQaumiZaban (National Language Authority) has consistently produced a significant quantity of Urdu publications, particularly bibliographical materials, and the Muqtadirah has released around 450(four hundred fifty) books. The National Academy of Letters Islamabad is Pakistan's most prominent and most illustrious learned organization. Since its inception in 1976, it has focused attention on and assisted Pakistani authors; it has aided in the development of local writing. The Academy has contributed 203(two hundred three) publications to date. In 1951, the Institute of Islamic Culture was founded in Lahore to foster Islamic theology and culture books.

According to their list of publications, the institution has released around 250 (two hundred fifty) books on various subjects. Iqbal Academy Pakistan Lahore was founded in 1962 to promote and propagate the study and comprehension of Allama Iqbal's writings and teachings. On their website, the Academy listed 115(one hundred fifteen) books in the English language and 187(one hundred eighty-seven) in the Urdu language as their publications (www.allamaiqbal.com) Bazam-e-Iqbal Lahore was founded in 1950 to foster the study, publishing on Iqbal's ideology and teaching and the bazam has published around 60(sixty) pieces. In 1976, the Quaide-Azam Academy in Karachi was founded. It is a nonprofit research and publishing organization dedicated to promoting works about Quaid I Azam, his companions, and the Pakistan movement. Since its founding, the Academy has produced more than 72 (seventy-two) books in English, Urdu, and other regional languages. The Urdu Dictionary Board (formerly the Urdu development board) was founded in 1958 to compile and publish a complete dictionary based on historical foundations. The first volume of this dictionary was published in 1977, and after 33 years, the dictionary is complete with volume 22, published in 2010. The board is assembling and creating a condensed edition and other smaller and specialized dictionaries (Siddiqui \& Naz, 2015).

The Islamic Research Institute was founded in 1960 to pursue and promote a comprehensive and insightful study of Is lam on a national and worldwide level. The institution has produced around 150 (one hundred fifty) publications on various Is lamic themes, the majority of which deal with Islamic law, history, philosophy, education, and Culture. In 1950, with the aid of UNESCO, the Pakistan Bibliographical Working Group was founded. Apart from the other commendable contributions, the publication of two of the three sections of Pakistan's Retrospective Bibliography, 1947-1961, is a magnificent achievement. The Government of Pakistan established the Pakistan Bibliographical Unit to produce the National Bibliography. As a section of the National Library of Pakistan in Islamabad, its primary mission is to print the National Bibliography regularly. 69 (sixty-nine) 
publications and reference works, mainly in Urdu, have been provided by the Library Promotion Bureau. Almost all Pakistan's public universities have a distinct bureau that collects, translates, and edits publications. Pakistan: Oxford University Press. The University of Oxford's Press in Pakistan is a subsidiary of the University. By publishing internationally, it contributes to the University's goal of excellence in research, scholarship, and education. The Oxford University Press (O.U.P.) Pakistan branch first opened its doors in 1952. The O.U.P. Pakistan's headquarters are in Karachi, with regional offices in Lahore and Islamabad. Shanul Haq Haqqee's Oxford English-Urdu Dictionary has become a standard reference book for scholars, journalists, instructors, and laypeople alike. At present, other than the above-stated organizations, the leading publishers such as Ariana-eAdab, Maktaba-e-Danyal, NayaIdarah, Feroz Sons, Sange-meel, Tariq Academy, Porab Academy, JamiaTalim-eMilliNazamia, Nigarishaat, Gosha-e-Adab, Shaherzad, Rang-e-Adab, Hamdard Foundation, Al Faisal, Beacon Books, Dar-ul -Salam, Welcome Book Port, Khazana e ilmo Adab, Urdu Academy Sindh, Taj Company, KutubKhana Shan-e-Islam, Islamic Publications, Islami Nazaryati Council, Royal Books, Pakistan Study Center: Universities of Peshawar, Karachi, Punjab, and others are having some considerable influence in publishing in Pakistan particularly in the Urdu language.

\section{Kinds of Book}

As a developing and usually thriving sector, book production necessitates a multitude of differences between book kinds (Encyclopedia Bratannica, 1998). Among them are the following:

Books For Education and Professional Development: Education and professional books are primarily concerned with training, and the majority of them are distinguished by their use of pedagogy (Learning materials), which includes characteristics such as learning goals, chapter recaps, and discussion questions. This category of publications includes business training manuals, college coursepacks, online textbooks, and text-related videos. Individuals who work in industries, corporate entities, government parastatals, and non-governmental organizations are familiar with this book. Books for Higher Education: These are books that concentrate on educating college students and post-college study. These books are beneficial for academic study since they aid in discovering new ideas in all fields of academic activity.

El-Hi Books are books aimed at elementary, middle, and high school students. These books are mainly aimed at kindergarten students. Increased orders for $\mathrm{El}-\mathrm{Hi}$ textbooks were placed due to the regular rise in student enrollment in the educational system. These kinds of publications foster a widespread commitment to statelevel education improvement. It enables district schools to continue purchasing textbooks and resources that need students' knowledge to be evaluated and tested concerning the texts. Consumer Books: Publishers of Consumer Books purposefully targeted the general audience with their goods. They are directed towards readers in their own lives. Apart from their responsibilities as students and highly skilled employees, informal teaching and noneducational genres account for a significant portion of consumer book production, including romance novels, humor books, and travel books. Outsourced corporate books: These books assist persons in the working class in remaining current in their areas of specialty while also advancing their knowledge. Outsourcing is contracting with a business to train a corporate employee rather than doing it in-house. Numerous firms have funded these educational endeavors, either in a classroom environment or through online programs. Trade Books: primarily comprised of general interest publications, including fiction and non-fiction, and are distributed to consumers through retail book shops (both conventional and online) and libraries. Mass Market Paperback Books: These are books that have a standard size and have a flexible cover. They are also available in smaller and pocket sizes. They are mainly intended for sale at newsstands, drugstores, bargain shops, and supermarkets.

\section{Impact of Book Publishing Industry on Society}

The book publishing industry has a significant influence on society. According to Lai (2000), book publishing is a serious business, an indicator of a nation's education, a cornerstone of cultural development, and a significant indicator of national growth. According to him, some of the critical impacts of the book publishing business on society include the following: (i). Book Publishing as a Business: Book publishing makes a sizable contribution to the Nation's economic development. It is a significant corporate enterprise contributing to literacy growth in science and technology, humanities, sociology, medicine, law, and politics. Naturally, it acts as a barometer for the Nation's socioeconomic progress. Manuscripts are examined based on their financial potential; a publisher must earn, and hence he needs to have a commercial mindset. Publishers collaborate relentlessly with the sponsoring Editor, who must persuade his organization's editorial Board of a book's financial viability before it can be published. Other factors to consider when budgeting a book are the cost of manufacturing, editing, the author's royalties, the cost of advertising, and overhead costs. All of them, however, are focused on maximizing earnings from the firm. (ii). Book Publication as a Development Tool: Book publishing promotes literacy, which accelerates national development. Valdehusa (1985) discusses the significance of literature in the process of national integration. According to him, "the quality, quantity, and variety of books produced by a civilization are significant markers of that culture's degree of development, intellectual sophistication, the potential for technical innovation, and entrepreneurialism." Valdehusa was attempting to demonstrate that book publication is an effective tool for human growth and behavioral transformation. Regardless, book publishing is the nerve center of education, assisting individuals in gaining complete control of their 
surroundings. Pakistani nationalists, for example, were able to confront and advocate for independence as a result of their western education. Roger (2002) acknowledges that development is a broadly participative process of social change in society aimed at achieving socioeconomic progress or improved quality, freedom, and other desired characteristics for the majority of people via their increased influence over their surroundings. (iii). Book Publishing as a Giant underground Cultural Framework: The publication of books contributes to the preservation and enhancement of cultural assets and values. The term "culture" refers to a group of people's ways of life. Its primary drivers are customs, tradition, language, and art; its components include history, political science, philosophy, linguistics, and anthropology. The publication of books in various academic fields has facilitated the methodical survival of our cultural values. Our renowned writers like Umera Ahmed, Ashfaq Ahmed, Wasif Ali Wasif, Ibn-e-Insha, Anwar Maqsood, Bano Qudsia, and Faiz Ahmad Faiz popularized several Pakistani artifacts, songs, and proverbs via their literary works. These creative works have evolved into a medium of teaching for today's youth. To summarize, book publication guides Culture toward civilization and reflects and enriches people's awareness of their society's habits, traditions, norms, and values. (iv). Employment Opportunities in Book Publishing: The fact that book publishers have not received the same level of glamour as their colleagues in the film business or other fields of human effort does not mean that the sector is a toothless bulldog when it comes to meaningful employment (Carte $\&$ Williams, 2001). The book publishing sector employs a large number of recent graduates and professionals who have taken relevant courses. Several opportunities are available for publishers, manuscript acquisition people, literary agent editors, designers, artists, typographers, printers, binders, marketers, sales representatives, promotion officers, and public re lations officers. (v). Book Publishing as a method of documentation Keeping; publishing books in any academic field serves as a record for future generations. Books that were published centuries ago continue to serve as a point of reference. For instance, if our oral history were published, most of it would have been evaluated and standardized scientifically. The documented and publicized actions of the prophet Mohammed enable the practice of Islam today. Thus, whatever is published today serves as the blueprint for what will become the accepted norm in the future.

\section{Problems of Book Publishing in Pakistan}

Publishing is a procedural profession, with various procedures that need to arrange tasks in several different ways. A variety of kinds of expert and unskilled individuals are tasked with carrying out these obligations. These actions are not limited to Pakistan; the same capabilities are available in other regions of the globe, including developed countries

\section{Finance}

In common with other players in the book publishing sector, the publisher is faced with several obstacles to overcome. Some of the most significant difficulties are described below:

Book publishing is considered to be a capital-intensive industry that generates a minimal return. In order to support their operations, the vast majority of publishers have difficulty raising sufficient funds. Furthermore, financial institutions such as banks are often wary about lending money to publishers for fear of not generating the desired profit or, worse still, losing the money entirely in the process. Due to the attitude of the financial institutions, the financial institutions have weakened the financial strength of the publishers, making operations challenging for them and resulting in a turnover that will be nothing to brag around. Even though the average net profit is modest, the bank interest rate is high. It is not easy to comprehend how the publishing sector has managed to thrive in this Nation, given the turnover rate, gestation time, and investment. It is vital to stress out right away that the low turnover of the publishing sector is not unique to Pakistan, where people have not yet developed the habit of reading for pleasure (Mustafa, 1982). A large proportion of reading continues to be for test or certificate purposes, even though the reading population is increasing due to educational growth at all levels. Due to low sales volumes and little turnover of deployable capital, publishers are forced to be conservative and careful in the number of books they produce.

Low print runs, on the other hand, imply higher unit costs for the books they print. According to Unwin (1976), the monetary return is seldom proportional to the work invested in a given circumstance. It is, in reality, considerably more challenging to make a living in publishing than is popularly believed, and anybody who might earn money in book publishing could likely make much more money in other companies. Weak Purchasing Power As a result of the economic crisis, the purchasing power of the typical Pakistani consumer has been severely diminished, further exacerbating the problem. Parents used to proudly purchase all of the books on their children's wish lists around two decades ago, but now that opportunity is no longer available. The second-hand book industry can be found everywhere, and the practice of 'passing down' books to newer generations has become fashionable. All of these have a detrimental impact on the publishing sector.

\section{Government}

The government of Pakistan is widely considered to be the most significant obstacle confronting the book publishing sector in Pakistan today. There is a negative attitude toward developing the book publishing industry in Pakistan among government officials. Policies governing the sector are not effectively applied, much alone subjected to proper supervision. It has not been widely recognized that the government, at all levels, is a key driver and enabler of the book publishing industry. 


\section{Poor Reading Culture}

According to a recent poll, $75 \%$ of Pakistanis have never read anything other than textbooks for their academic studies. Only nine percent of the population is a voracious reader. However, although the survey does not specify what the other participants are doing with their time, it is not impossible to surmise that the vast majority are just squandering their time on social media or their iPhones. In Pakistan, there is an urgent need to revitalize the culture of book reading. Many people's book reading habits have been ruined by the social media and mobile culture of today. Readers who are encouraged to purchase and read at least one book per month may help to revitalize the reading culture in their communities. In addition to lowering the expense of books, the government may play a role by arranging reading programs and promoting literacy (Faridoon, 2020). Reading Culture and mindset are being extinguished daily, particularly in our digitally connected age. Reading in Pakistan is mainly to prepare for examinations or obtain certificates. As Tiamiyu (2005) points out, a strong book reading Culture serves as a foundation for the growth and development of the publishing sector. He also observed that the market for book publication in Pakistan is restricted due to the Pakistani public's negative attitude toward the habit of reading books. 'Individual Difference Theory' impacts the desire to read since a book's selection is based only on the reader's interest in the subject matter. According to Baran \& Davis (2007), this is a study of how the media affects people. What has been the media's impact on the readership in a more literal sense? How have the media (books) affected us as people in terms of convincing us? Individual Different Theory (Agbo \& Fab-Ukozo, 2000) examines how the mass media affects readers with varying characteristics, as the name implies. Some media messages will have a more significant impact on some sorts of people than others.

For example, it seems that men are more impacted by novels with violent or criminal themes while females are more influenced by the "body image" of their media models in books about romance and fashion and books about managing a house or kitchen. When it comes to logical appeals, well-educated readers may be more openminded to the message. Among the many demographic factors that influence how a book affects a person are gender and educational attainment and age, place of residence, religion, intellectual level, socio-economic class, degree of sexual assault, and financial security, among other things. Because one man's interest in a topic may be another's disposition, an individual difference hypothesis is based simply on this fact. James (2013, online) asserts that a Pakistani teenager is indifferent in reading literature, most notably if they are well out of their fields. They have lost interest in books because of the internet's social networking sites. The quality of the information provided to end-users is unaffected by this exposure, regardless of the end users' mental and social development level. This is a novel approach to book reading that allows readers to get a deeper understanding of both their character and the values of the larger community. Since so many people read books, this leads to sharper reasoning and better spelling abilities.

\section{Intellectual Property}

Intellectual property law is concerned with the rights associated with an intangible or incorporeal property. When an author produces a literary work, the author has some rights analogous to physical or tangible property ownership. The purpose of copyright law is to protect inventors and other intellectual property providers by allowing them an exclusive right to limit the use of their works. In general, governments create their intellectual property laws to codify moral and economic innovations, to promote, as a purposeful act of government policy, invention, distribution, and application of its findings, and to promote fair trade that may contribute to economic and social growth (Jain \& Rai, 2005). In the past two decades, the relevance of copyright law has grown tremendously, and its impact on the area of information technology has been revolutionary. Copyright law has a direct impact on the collection, processing, and distribution of information. Because piracy directly impacts the country's current economy, it comes within the definition of an economic offense (Basit, 2013). Copyright of Pakistan and literature analysis on the issue of book piracy in Pakistan, and Pakistan has a significant problem with book piracy, which has both economic and political consequences. It is complicated to enforce regulations in Pakistan, which makes it much more challenging to regulate piracy. Pakistan has been on the 301-watch list since 1989 because of this issue. Therefore, this research aims to investigate the elements that contribute to Pakistani book piracy.

Piracy is the illegal use of copyrighted material without permission (Netanel, 2007). In order to instill in individuals the idea that copyrighted works are inviolable, warnings against copyright infringement are sent from all angles (Shah, 2005). It is unlawful and unethical to copy someone else's intellectual property without permission or agreement (Nkiko, 2014). 90\% of books are imported from the United Kingdom and the United States to suit the educational needs of local institutions (Haider, 1993). The copyright-protected version of foreign books is out of reach for Pakistani students. Their dependence on illegal copies of foreign publications rises in this way (Shah, 2005). According to the National Education Policy 19982010, libraries at all levels of education should be provided with the most up-to-date resources and services. Pakistan's rising imports of Indian printed technical and religious publications are a factor in this business growth. Book piracy is a problem in Pakistan for a variety of reasons. Lack of public knowledge, lack of vigilance and enforcement mechanis ms of copyright laws, high costs of foreign books, significant profit, technical issues, and obstacles in importing foreign editions of books are among the most prevalent contributing reasons (Bashir \& Khan, 2016). 
However, this issue has grown more chronic due to our disregard for intellectual property rights (Younas, 2011). The review of literature depicts various causes of piracy in Pakistan, including misconceptions about piracy, as the public frequently considers piracy a means of having access to cheaper as well as good versions of books, but they completely ignore the effects of piracy on creativity; secondly, there is a superficial level of public awareness, people do not even realize that it is a criminal activity and how an ordinary man contributes to the spread of unlawful practices; and thirdly, access to legitimate sources (Bashir, 2015). There are other issues, such as a lack of literacy regarding copyright. The Cost-Benefit Analysis, Dissatisfaction with the Lack of Available Materials for Study and Research According to the Legal Discourse, copyright holders often get into unethical negotiations with publishers. The country's image at the international level, The IPO is the single organization in Pakistan that deals with all Intellectual Property Rights (IPR). It intends to centralize the issue and regulation of trademarks, patents, and copyrights under a single governmental authority (www.ipo.gov.pk). Infringement of copyright laws is referred to as copyright infringement. Piracy is the most widespread kind of copyright violation. Piracy is the intentional violation of intellectual property copyright and a complete disregard for literary work ownership or authorship (Mahmood \& Illyas, 2005). According to the report, various reasons contribute to this occurrence, including user misunderstandings about piracy, a poor level of literacy on the side of users, challenges in getting authorized works in developing countries such as Pakistan, and cumbersome legal processes. Piracy has harmed Pakistan's worldwide image in the case of foreign content. Some analysts believe that Pakistan is a haven for pirated publications, both foreign and domestic. Piracy is often defined as the intentional violation of copyright and complete disregard for the ownership or authorship of literary works. The problem of book piracy is rooted in social, economic, scholarly, and legal factors.

\section{Piracy}

Copyright is private property, and any unauthorized use is considered piracy (Netanel, 2007). Piracy is defined as the unauthorized reproduction or circulation of the author(s)' inventive, protected work as a whole or a substantial portion of it. Alarms against the offenses of copyright infringement emanate from all directions to instill in people the inviolability of copyrighted works. The concept of creativity and authorship is inviolable, making it all the more important to safeguard it against pirates. If we do not do so, we will be serving a death warrant on innovation (Shah, 2005). Book piracy is the unauthorized and unlawful replication of another's work for any cause without the approval or authority of the intellectual property owner (Nkiko, 2014). The expansion of Pakistan's higher education sector has boosted the need for reading materials in educational institutions.

The textbook boards are attempting to address the is sue at the school level; however, there is a scarcity of books on professional subjects such as engineering, medicine, business, and law, among others. The industry of book publishing is evolving all over the globe; technological advancements have revolutionized its operations, and the consequences are being felt all over the world. As a result, book publishing has expanded outside its conventional boundaries. Modern machinery, particularly in industrialized countries, makes book creation simpler and quicker than ever before. When it comes to technology, the Pakistan publishing business suffers from an epileptic state, and publishing enterprises in the country must acquire current technology to remain competitive with the world wide trend. To fulfill the educational needs of local institutions, $90 \%$ of books are imported from overseas, mainly from the United Kingdom and the United States of America (Haider, 1993). Teachers in the majority of public and private sector academic institutions rely on pirated foreign editions of books. Under normal circumstances, however, an average Pakistani student cannot afford to purchase the copyright shielded version of foreign books. In turn, it increases their reliance on unauthorized copies of international works (Shah, 2005).

Piracy has entirely taken over Pakistan's academic market. English courses in elementary and secondary schools often use pirated copies of literature. Piracy at the university level is considerably worse, with rates exceeding 90\%. On the other hand, Publishers claim a more significant percentage of genuine sales of reference products to libraries. It is most likely due to the expensive cost of creating these resources and the relatively limited market over which to distribute production expenses, making this market unappealing to pirates trying to make a significant profit. It might also be attributed to the Pakistani government's National Education Policy 19982010, which stipulates, in part, that school, college, and university libraries will be equipped with the most recent reading materials/services. Increased imports of Indianprinted technical and religious titles contribute to this surge in business in Pakistan. The problems inherent in a system that generates demand from India include suspicion that shipments from India are mixed, containing pirate books, Indian-only reprints, and copies that are legal for distribution in Pakistan; and general hostility among many people to having India supply Pakistan with books on cultural/social/political grounds.

Nonetheless, supplying approved books from India may be a method for legal right holders to acquire a foothold in a hitherto impenetrable market in the near run (Polar Star Report, 2010). The United States asked Pakistan to enforce copyright rules in order to combat book piracy aggressively. The European Union and the United States have put considerable pressure on Pakistan to investigate this matter to defend foreign writers' rights (Mahmood \& Illyas, 2005).

There are many causes of book piracy in Pakistan. Lack of public knowledge, lack of monitoring and regulatory mechanis ms of copyright laws, high costs of foreign books, significant profit, technical issues, and problems in importing foreign editions of books are the most prevalent 
contributing causes (Bashir \& Khan, 2016). However, owing to our disrespect for copyrights, this issue has grown more chronic. Piracy is encouraged by the failu re to prosecute people engaging in such acts. In Pakistan, intellectual property legislation is quite explicit and rigorous, but the enforcement system is poor, and legal recourse is time-consuming and costly. If the government wishes to encourage a book culture in Pakistan, it should take drastic action against individuals participating in this trade and apply the Copyright Act (Younas, 2011). The literature review portrays different causes of piracy in Pakistan, such as misconceptions about piracy, as the public frequently considers piracy a means of having access to cheaper as well as good versions of books, but they completely ignore the effects of piracy on creativity; secondly, there is a deficient level of public awareness, people do not realize that it is a criminal activity and how an ordinary man contributes to the spread of unlawful practices; and thirdly, access to legitimate sources.

\section{Distribution and Marketing}

When it comes to Pakistani book publishing, book distribution and marketing are sometimes woefully insufficient. Since the publishing industry is still expanding, professional experience in bibliographic work and marketing is in short supply. A consequence of this underfunding is that the publishing sector in Pakistan is undercapitalized. Most printers function as their publishers and distributors due to their failure to recruit the appropriate kind and number of employees in certain of their activities

\section{Dearth of Expertise}

In Pakistan's book publishing sector, technical knowledge in several departments is lacking. As a result, the market places are flooded with poorly edited, poorly written, and substandard books. The industry is financially incapable of meeting these professions' expectations for compensation, allowances, housing, and welfare, of naming a few. Additionally, the profit margins on book publication are absurd, which significantly impedes attempts to incorporate knowledge into the processes. Perpetual Discord Among the Key Stakeholders, the relationship between writers and publishers, is far from harmonious. For instance, many writers believe that publishers defraud them by earning large sums of money but paying tiny royalties; publishers, on the other hand, accuse authors of double-dealing. As a result of this misunderstanding, several commendable and feasible initiatives have been abandoned due to a lack of mutual understanding and collaboration. Conflicts amongst the industry's essential and primary participants bode positively for the sector's development.

\section{Technology}

The industry of book publishing is evolving all over the globe; technological advancements have revolutionized its operations, and the consequences are being felt all over the world. As a result, book publishing has expanded outside its conventional boundaries. Modern machinery, particularly in industrialized countries, makes book creation simpler and quicker than ever before. When it comes to technology, the Pakistan publishing business suffers from an epileptic state, and publishing enterprises in the country must acquire current technology to remain competitive with the worldwide trend.

\section{Conclusions}

In every community, books are a dynamic product and a colossal cultural asset. Students, researchers, and the general public alike will find it a treasure chest of information, as well as enjoyable and relaxing reading. A book is an indicator of growth, a stabilizing force, a source of inspiration, and a springboard for a breakthrough. Thus, it is the responsibility of all parties, both public and private, to support the book publishing business, particularly in this era of democracy, to bring Pakistan to the shores of stability and progress. When you think about it, the primary goal for book publication is just extending the boundaries of knowledge from generation to generation. It is all about supporting learning and extending one's knowledge via publishing. Book publication must be handled more seriously than ever before based on this idea. The business's stakeholders should work together to come up with creative solutions to the industry's problems.

It is illegal to infringe on someone else's copyright. Piracy is the most widespread violation of copyright law. Pirates deliberately breach copyright and disrespect the ownership or authorship of literary works to gain an advantage in the marketplace (Mahmood \& Illyas, 2005). Findings from the research show several reasons at play, including a lack of literacy among the general public, problems in getting original works in a developing nation like Pakistan, and cu mbers ome legal processes. Piracy has harmed Pakistan's worldwide image when it comes to foreign content. International and local pirated publications are plentiful in Pakistan, according to some specialists. The study also concluded that the sector should be closely watched and tightly controlled because of the positive effects it may have on people's mental health and the economy of the country. It is a symbiosis of several activities.

\section{Recommendation}

As a result of this research's recommendation that all stakeholders in the publishing business work together and give their quota to the construction of a virile publishing sector, the study concludes: Investment from private investors such as banks and financial companies should be encouraged in terms of large-scale capital injections. Similarly, the government must work with important nongovernmental groups to organize book clubs in our schools around the country, which will help to cultivate a reading culture among our children. It is time for the government to begin implementing regulations to end the 
plague of book piracy and bring pirates to justice. The government should reduce import tariffs on bookpublishing equipment and accessories to promote the smooth importation of all of them. In order to keep their technical staff productive, publishing companies should make it a policy to provide them with regular professional development opportunities. Authors should be given all the financial and moral support they need to produce highquality in formation sources in their language. Strong book culture in a nation is a significant factor in a person's desire to read. As a result, the govern ment should promote book clubs, book weeks, and book fairs to boost reading habits. Annual book exhibits should be organized around the nation and should occur regularly. Bookselling or publishing should be regarded as a business, and more precisely, a challenged one. To allow for the free flow of books, all breakers should be removed. It is necessary to exclude import tariffs on raw materials such as papers and boards, ink, lead, zinc plates, re lated material, and printing and binding gear. According to the NDFC report's suggestion, a national book development bank should be established to help fund book sales and publication. Copyright laws need to be updated to keep up with changing social, economic, and technical circumstances. Authors' rights and other intellectual property concerns must be protected by intellectual property owners (I.P.O.) in Pakistan, and book piracy must be controlled. According to the findings, students and faculty in Pakistan might benefit academically by including Intellectual Property Laws in their law schoolcurricula

\section{References}

[1] Khalid, A. (1994). My Forty Years of Book Production InReaders on BookIndustry in Pakistan.Saad, I \& Ivan, K. (Ed.) Karachi: Royal Books \&Mashal Pakistan.

[2] Altbach, P. \& Rathgeber, Eva M. (1980) Publishing in the Third World: Trend Report Bibliography. New York: Preager.

[3] Awoniyi, A. [1997], Publishing In Nigeria In The 21stCentury: Prospects And Challenges,Pergamon Press, Oxford Press.

[4] Kalejaiye, O. and A kangbe, C. (2007) Book Publishing and Its Challenges: The Nigerian Experience. International Journal of Communication, 7, 71-72.

[5] Carter , R.A . And Pattis, W. S. [2001], Opportunities In Publishing Careers. V.G.M. Career Books. Illinois.

[6] Shah, Syed Mahmud. 1963. "Book Distribution in West Pakistan," in N. San karanarayanan (ed.), Book Distribution and Promotion Problems in South Asia. Paris, Madras, Higginbothams: UNESCO, pp. 21-29.

[7] PBWG (Pakistan Bibliographical Working Group). 1972. The Pakistan National
Bibliography, 1947-1961. Vol 2. Karachi: National Book Centre of Pakistan.

[8] Bradley, M. M., \& Lang, P. J. (2000). Measuring emotion: Behavior, feeling, and physiology. Cognitive neuros cience of emotion, 25, 49-59.

[9] Merton, R.K. (1957) Social Theory and Social Structure. Glencoe, IL: Free Press.

[10] McQuail, D. (2000). Mass communication.

[11] Grannis, C. [1967], What Happen In Book Publishing. University Press, Columbia, U.S.A.

[12] Olan iawo, W. [1996], Nigeria: An Overview Of Its Publishing Landscape, Nigeria Publisher's Association, Ibadan. 3[2] , PP25-28.

[13] Lai Oso el tal (2000), Book Publishing: A Practical Guild, African Resource Press, Mushin, Lagos.

[14] Abu lHassan (1994) Comparing Pakistan and Indian Publishing In Readers on BookIndustry in Pakistan.Saad, I. \& Ivan, K. (Ed.). Karachi: Royal Book \&Mashal Pakistan.

[15] Ali, S. A. (1967) Book World of Pakistan. Karachi: National Book Center of Pakistan.

[16] Samiullah. (1988) Uneesween saddi mein Urdu ke tasnifi idary. Lukhnao: Samiullah.

[17] Minault, G. (1999). Delhi College and Urdu.

[18] Aqeel,M.U.(2014) Junoobi Asia meintabaatkaaaghaz o irtiqa:

[19] Musalm an on kitabaatis argarme aurquamibedari .Karachi : Shobalblagh e Aama, Jamia Karachi.

[20] Sheikh, Rafia Ahmed. "Book Publishing in Pakistan." Pakistan Library Bulletin 20, no. 1 (1989): 1-32.

[21] Siddiqui, R. P., \& Naz, F. (2015). Publishing of Urdu books in Pakistan: An analytical study from 1947 to 2007. Journal of Mass Communication Department, Dept of Mass Communication, University of Karachi, 12.

[22] Rogers, E. (1971), Communication Of Innovations, Free Press Limited, New York, USA.

[23] Valdehusa, M.E. (1985). "Book Publishing: An Underrated Industry". Journal of Reading. Newark: International Reading Association, Vol. 28, No. 8, p.710.

[24] Mustafa, Z. (1982, October 31). Publishing industry's travail: Book production a high risk business | Zubeida Mustafa. Zubeida Mustafa. Retrieved November 12, 2021, from http://www.zubeidamustafa.com/publishingindustrys-travail-book-production-a-high-riskbusiness.

[25] Unwin, S. (1976). The'Truth About Publishing. London: George Allen \& UnwinLtd.

[26] Faridoon Burki. (2020, October 27). Book reading culture. DAWN.COM. https://www.dawn.com/news/1587258

[27] Netanel, N., W. (2007). Why copyright has expanded? Analysis and critique. In Fiona Macmillan \& Edward Elgar (Eds). 6 new 
directions in copyright law. USA: UCLA School of Law.

[28] Shah, A., K. (2005). The World Trips over Berne. Intellectual Property. LW 556 USTR (2018). Special 301 Report. Retrieved from https://ustr.gov/

sites/ default/files/files/Press/Reports/2018\% 20Special $\% 20301 . p d f$

[29] Nkiko, C. (2014). Perspective on Book Piracy in Nigeria: Issues and Strategies. The Journal of Academic Librarianship. 40, pp. 394-398

[30] Haider, S., J. (1993). Acquiring Foreign Materials for Pakistani libraries. Unpublished doctoral dissertation. USA: Loughborough University of Technology.

[31] Mahmood, K., and Ilyas, M. (2005). Copy Right and Book Piracy in Pakistan, IFIA Journal. p.324

[32] Bashir, S., and Khan, G. (2016). Book piracy and legal lacunae in Khyber Pakhtunkhwa: A legal professionals" view point, Journal of Law \& Society. 48(68).

[33] Younas, H. (2011). Book piracy in Pakistan. Retrieved from https://www.dawn.com /news/603599.

[34] Bashir, S. (2015). Book piracy and legal lacunae in Pakistan: Focus on Khyber Pakhtunkhwa. Unpublished LLM thesis. Peshawar: Law College, University of Peshawar.

[35] Piracy in Pakistan. Retrieved from the Polar Star http://www.thepolestar.org /piracyinpakistan.aspx

[36] Baran, S. and Davis, D. 2007. Mass Communication Theory: Foundations, Ferment and Future, 4th ed. India; Anubha Printers, p. 149.

[37] Agbo, B. and Fab-Ukozor, N. 2000. Mass Communication: Purpose, Principle and Practice. Enugu: John Jacob's Classic Publishers Ltd. P. 43.

[38] James, I. J. (2013, Jan., 16). http://unllib.unl.edu/LPP/PNLA\%20Quarterly/ja mes 75-3.htm.

[39] Jain, P., and Rai, S.P. (2005). Copyright and Trademark Law, Related to computers (1st edition). Kerala: Eastern Book Company.

[40] Basit, M.A (2013). Intellectual property law. Rawalpindi - Lahore: Federal Law House.

[41] Robinson, Francis. 1993. "Technology and Religious Change: Islam and the Impact of Print," Modern Asian Studies 27, pp. 229-251.

[42] Pickett, Catherine. 2011. Bibliography of the East India Company: Books, Pamphlets and Other Materials Printed Between 1600 and 1785. London: British Library.

[43] Green, Nile. 2009. "Journeymen, Middlemen: Travel, Trans-Culture and Technology in the Origins of Muslim Printing," International Journal of Middle East Studies 41, pp. 203-224
[44] Suzuki Takeshi, Tanaka Toshio. 1974. "On "Munshi Nawal Kishor"," Area and Culture Studies 24, pp. 99-125

[45] Punjab Government. 1989. Gazetteer of the Lahore District, 1883-4. Lahore: Sang-e-Meel Publications.

[46] Shamsuddoulah, A. B. M. ed. 1970. Pakistan Library Directory: a Classified List of Libraries in Pakistan with Personnel and Statistical Data, a List of Major Publishers and Booksellers, a Bibliography of Pakistan Librarianship, and an Area Index. Dacca: Great Eastern Books

[47] UNESCO. 1980. Unesco Regional Centre for Book Development in Asia and the Pacific (Pakistan). Report of Conference: Regional Seminar on Book Publishing in National Languages. Karachi: Unesco Regional Office for Book Development in Asia.

[48] Bengali Academy. 1964. What People Read in East Pakistan. Karachi: National Book Centre of Pakistan.

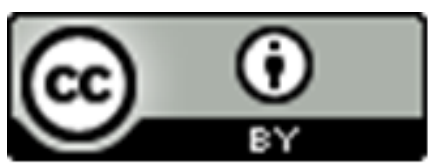

